\title{
Proximate Analysis, Phytochemical Screening and Antitrypanocidal Potentials of Bucholzia Coriacea in Trypanosoma Brucei Brucei- Infected Mice
}

\author{
Okere O. Shekins ${ }^{1}$, Iliemene Uju Dorathy*1 ${ }^{1}$, Tese Timothy ${ }^{2}$, Mubarak Liman ${ }^{3}$, \\ Olowoniyi Olufunsho Dayo ${ }^{4}$ \\ ${ }^{I}$ Department of Biochemistry, Bingham University, karu, Nigeria. \\ ${ }^{2}$ Nigerian Institute for Trypanosomiasis Research (NITR), kaduna, Nigeria. \\ ${ }^{3}$ Department of Biochemistry,Ahmadu Bello University, Zaria, Nigeria. \\ ${ }^{4}$ Department of Science Laboratory Technology, Fedral Polytechnic, Nasarawa, Nigeria.
}

\begin{abstract}
The proximate analysis of the Bucholzia coriacea seeds according to AOAC (1990) shows appreciable amount of nutrients with highest carbohydrate content (77.20\%) and moisture content having the lowest value (1.34\%). There was presence of phytochemical compounds in the seeds as well. The trypanocidal potentials of aqueous and methanolic extracts of Buchholzia coriacea investigated intraperitoneally in trypanosome induced mice using parasitized blood of mice infected with Trypanosoma brucei brucei strains $(0.1 \mathrm{ml}$ of diluted blood from infected mice having an average of 100 parasites per microscopic field) confirmed infection by microscopic examination of blood samples obtained from the tail of the mice after 96hours of inoculation. The number of parasites per field was noted and the general clinical conditions of the mice were monitored. The packed cell volume was determined using a haematocrit centrifuge. The extract cleared the trypanosomes in the blood between the $11^{\text {th }}$ and $13^{\text {th }}$ day post infection, after 5 consecutive days treatment with $1000 \mathrm{mg} / \mathrm{kg}$, the level of parasitaemia was significantly lower than those of the $250 \mathrm{mg} / \mathrm{kg}$ and $500 \mathrm{mg} / \mathrm{kg}$ and the infected untreated groups in the aqueous extract than those treated with methanolic extract. There was no difference between the level of parasitaemia of the Berenil treated group and the $1000 \mathrm{mg} / \mathrm{kg}$ of the extract treated group from the $7^{\text {th }}-13^{\text {th }}$ day Post infection. The Berenil treated group and $1000 \mathrm{mg} / \mathrm{kg}$ had a significant increase in the level of packed cell volume than the $250 \mathrm{mg} / \mathrm{kg}$ and $500 \mathrm{mg} / \mathrm{kg}$ treated groups with aqueous extract. In conclusion, the group treated with aqueous extract exhibited trypanocidal activity than the group treated with methanolic extract of Buchholzia coriacea especially at $1000 \mathrm{mg} / \mathrm{kg}$.
\end{abstract}

Keywords: Proximate analysis, phytochemical screening, antitrypanocidal, Bucholzia coriacea,Trypanosoma brucei brucei

\section{Introduction}

Many natural food products are reported to have nutritional as well as medicinal capabilities (Atawodi, 2005). Medicinal plants are known for their healing properties especially in the rural areas. They are used in curing ailments of man and animals. They are a cheap source of medicine and many pharmaceutical companies derive their active principles from such plants. Approximately 119 pure chemical substances extracted from higher plants are used in medicine throughout the world (Arowolo, 1997). Plants have been sources of medicines for many generations. More than $80 \%$ of the population in developing countries depends on plants for their medical needs according to (Focho et al., 2009). It has been reported that about 2/3 of all plant species are found in the tropics.

African animal trypanosomiasis (AAT) is mainly caused by T. congolense, T. vivax and T. b. brucei. It is one of the most important diseases of domestic livestock in sub-Saharan Africa. The disease is most important for cattle but also pigs, camels, goats and sheep are affected (Aderbauer et al., 2008). Infections of livestock as well as companion animals like dogs with T. congolense and T. b. brucei are very common especially, in South Eastern Nigeria. (Omamegbe et al., 1984).Trypanosomiasis is endemic in this part of the world. This is because of the typical rain forest ecology which favours the growth and spread of the tsetse flies responsible for the 
disease transmission. Trypanosomiasis is a major setback to animal production in this area since virtually all livestock species are susceptible to one or more species of trypanosomes.

Control of trypanosomiasis is mainly by chemotherapy however, few drugs are presently available. The available drugs are old, toxic and often too expensive for the rural farmers. There are often cases of relapse of infection after treatment and of growing parasite resistance. All these underscore the need for new, effective and inexpensive drugs for the treatment of trypanosomiasis. Plants have always been among the common sources of medicaments, either processed as traditional preparations, or used to prepare pure active principles (Freiburghaus et al., 1996).In Africa, herbal treatment has a long tradition and still holds a strong position in medical care. In Nigeria, traditional healers use medicinal plants either alone or in combination to treat both human and animal trypanosomiasis (Wurochekke and Nok, 2004). Several reports exist on the herbal treatment of sleeping sickness (Asuzu and Chineme, 1990; Asuzu and Anaga, 1991; Wurochekke and Nok, 2004).

\section{Materials and methods}

\section{Sample collection and authentication}

The seeds of Bucholzia coriacea Engl. Were purchased from Old Karu market in Abuja, Nigeria in November 2012. The plant was identified at the Herbarium Unit of the National Institute for Pharmaceutical Research and Development (NIPRD), Idu, Abuja, Nigeria.

\section{Sample preparation and extraction}

The seeds of Bucholzia coriacea were chopped into small pieces and dried in the laboratory at room temperature which was pulverized using laboratory mortar and pestle. Pulverized material $(150 \mathrm{~g})$ was placed in the thimble of Soxhlet extractor and extracted first using hexane for 72 hours each (to remove the lipid content) and then $80 \%$ methanol $(750 \mathrm{~g})$. The methanol extracts were combined and dried in vacuo at $45^{\circ} \mathrm{C}$ using a rotary evaporator and the percentage yield was determined as follows:

$$
\text { Percentageyield }(\%)=\frac{\text { weight of the plant extract }}{\text { weight of the dried plant extract used }} \times 100
$$

\section{Preparation and concentration of aqueous extract}

Fresh Buchholzia coriacea seeds were cut into pieces and pulverized. 200g of the pulverized sample was weighed and $500 \mathrm{ml}$ of distilled water was added to it. The solution was mixed and left for about 24 hours after which it was filtered. The aqueous extracts were then transferred to a rotary evaporator at $3000 \mathrm{rev} / \mathrm{min}$ at $95^{\circ} \mathrm{c}$ and further concentrated by evaporation on a water bath at $100^{\circ} \mathrm{c}$ for one hour then stored in sample bottles and the percentage yield determined as follows:

$$
\text { Percentageyield }(\%)=\frac{\text { weight of the plant extract }}{\text { weight of the dried plant extract used }} \times 100
$$

\section{Proximate analysis of Bucholzia coriacea seeds}

Moisture content, crude protein, crude fat, ash, and carbohydrate were determined using AOAC,(1990) method.

\section{Ash content Determination}

$5 \mathrm{~g}$ of the crude extract was weighed in a crucible and incinerated in an oven at $300^{\circ} \mathrm{C}$ for 3 days. The weight after incineration was taken. The ash content was determined using the formula;

$\%$ Ash content $=\frac{\text { Loss in weight after incineration }}{\text { initial weight of crucible and extract }} \times 100$

\section{- Crude fat}

Crude fat was determined by defatting the known weight of the seed sample of $5 \mathrm{~g}$ in $25 \mathrm{ml}$ petroleum ether for $30 \mathrm{mins}$. The supernatant was decanted into weighed crucibles and oven dried for $45 \mathrm{mins}$ at $103^{\circ} \mathrm{C}$.

$$
\begin{aligned}
& \% \text { Crude fat }=\frac{\text { Loss of weight of supernatant }}{\text { weight of sample used }} \times 100 \\
& \% \text { Crude fibre }=\frac{\text { Loss in weight after drying for } 2 \text { hours }}{\text { weight of sample used }} \times 100
\end{aligned}
$$




\section{- Carbohydrate determination}

This was determined using Benedict's reagent method; 5 drops of the crude extract was added to $2 \mathrm{ml}$ of Benedict's reagent and placed in a boiling water bath for $5 \mathrm{mins}$. A corresponding rust- brown colour was observed indicating the presence of carbohydrate.

$$
\% \text { carbohydrate }=\frac{\text { Loss in weight after drying for } 2 \text { hours }}{\text { weight of sample used }} \times 100
$$

\section{- Crude protein}

Presence of protein was determined by adding $1.5 \mathrm{ml}$ of Biuret reagent to $1 \mathrm{ml}$ of the extract; it was mixed and allowed to stand for $15 \mathrm{mins}$. A corresponding light purple colour was observed, indicating the presence of protein.

$\%$ crude protein $=$

$\mathrm{A}=$ Vol. (mL) std. HClx Normality of std. $\mathrm{HCl}$

$$
\% \text { Nitrogen (wet) }=\frac{\mathrm{A}-\mathrm{B} \times 1.4007}{\text { weight }(\mathrm{g}) \text { of sample }} \times 100
$$

$\mathrm{B}=$ Vol. (mL) std. $\mathrm{NaOHx}$ Normality of std. $\mathrm{NaOH}$

$$
\begin{aligned}
\% \text { Nitrogen }(\text { dry }) & =\frac{\% \text { Nitrogen }(\text { wet })}{100-\% \text { moisture }} \times 100 \\
\% \text { Protein } & =\% \text { Nitrogen } \times 6.25
\end{aligned}
$$

Where 6.25 is the protein nitrogen conversion factor for fish and fish by- products.

\section{- Moisture content}

In determining the moisture content, exactly $10 \mathrm{~g}$ of the extract was dried at $103^{\circ} \mathrm{C}$ to a weight in an oven.

$\%$ Moisture content $=\frac{\text { Loss in weight after drying for } 2 \text { hours }}{\text { weight of sample used }} \times 100$

\section{Phytochemical analysis}

Qualitative phytochemical analysis of partitioned fractions was carried out by using standard procedures to identify the constituents as described by Edeoga et al., (2005) and Parekh and Chanda (2007).

Alkaloids: To identify presence of alkaloids, $4 \mathrm{~mL}$ of $1 \% \mathrm{HCl}$ was added to $0.25 \mathrm{~g}$ of plant fraction and then warmed and filtered. To $1 \mathrm{ml}$ filtrate 6 drops of Mayor's reagents/Dragendroff reagent was added separately. Creamish precipitate/orange precipitate indicated the presence of alkaloids.

Saponins: (Frothing test). To detect saponins, $0.5 \mathrm{~g}$ of the plant fraction was boiled in $5 \mathrm{~mL}$ of distilled water. After cooling, it was shaken vigorously to produce stable persistent froth.

Anthraquinones: To check presence of anthraquinones, $0.5 \mathrm{~g}$ of the plant fraction was boiled with $3 \mathrm{~mL}$ of $1 \%$ HCland filtered. To filtrate, $2 \mathrm{~mL}$ of benzene was added and well shaken. The benzene layer was removed and fewdrops of $10 \% \mathrm{NH}_{4} \mathrm{OH}$ was added. Formation of pink, violet or red colour indicated the presence of anthraquinones.

Terpenoids (Liebermann-Burchard reaction): To identifypresence of terpenoids, $0.5 \mathrm{~g}$ of the plant fraction was dissolved in $2 \mathrm{~mL}$ of chloroform and filtered. To filtrate,equal volume of acetic acid and a drop of conc. $\mathrm{H}_{2} \mathrm{SO}_{4}$ was added. Blue-green ring indicated the presence of terpenoids.

Flavonoids, Flavones: To detect flavanoids and flavones, $0.5 \mathrm{~g}$ of the fraction was washed with petroleum ether. The defatted residue was dissolved in $20 \mathrm{~mL}$ of $80 \%$ ethanoland filtered. The filtrate was used for the following test; 
a) About $3 \mathrm{ml}$ of the filtrate was mixed with $4 \mathrm{ml}$ of $1 \% \mathrm{AlCl}_{3}$ in $\mathrm{MeOH}$ in a test tube. Formation of yellow colour indicate the presence of flavones.

b) About $3 \mathrm{ml}$ of the filtrate was mixed with $4 \mathrm{ml}$ of $1 \% \mathrm{KOH}$. A dark yellow colour indicate the presence offlavonoids.

Tannins: To test for tannins, $0.25 \mathrm{~g}$ of plant fraction was boiled in $10 \mathrm{ml}$ of distilled water and filtered. Then $1 \% \mathrm{FeCl}_{3}$ was added to the filtrate. Brownish green or a blue-blackcolouration indicate the presence of tannins.

Cardiac Glycosides: (Keller - Kiliani Test). To detectcardiac glycosides, $2 \mathrm{ml}$ of glacial acetic acid and few dropsof $1 \% \mathrm{FeCl}_{3}$ was added to $0.5 \mathrm{~g}$ of plant extract. It was then underlayed with $1 \mathrm{ml}$ of conc. $\mathrm{H}_{2} \mathrm{SO}_{4}$. Greenbluecolour indicate the presence of cardiac glycosides.

\section{Animal management}

Thirty healthy Wister mice of both sexes weighing about 20-32g were obtained from the animal unit of the Institute for Trypanosomiasis Research (NITR) Vom Jos, Plateau state, Nigeria. The mice were housed in steel cages and kept at room temperature maintained in accordance with the recommendation in the Guide for the care and use of laboratory animals (DHHS, NIH Publication No. 85-23, 1985). They were kept for a period of 21 days before the start of the experiment. They were fed on pelleted commercial growers mash (VitalFeeds, Jos, Nigeria) and tap water before and all through the experiments.

\section{Induction of trypanosoma brucei brucei and experimental grouping}

Trypanosoma brucei brucei (purchased from Nigerian Institute for Trypanosomiasis Research (NITR) Kaduna State, Nigeria) was induced in the experimental mice following the method of Herbert et al., (1976). The innoculated Trypanosoma brucei brucei were dissolved in $10 \mathrm{ml}$ of normal saline, and then $0.1 \mathrm{ml}$ of this Trypanosoma brucei brucei solution was induced intraperitoneally from infected mice having an average 100 parasites per microscopic field. Infection was confirmed by examining blood taken from the mice at regular intervals of 48hours throughout the period of the experiment. Parasitemia was confirmed by observing a sample of blood obtained from the tail of infected mice under light microscope (x40) and noting the average number of parasites per field and also monitoring the general clinical condition of the mice throughout the period of the experiment.Oral administration of $250 \mathrm{mg} / \mathrm{kg}, 500 \mathrm{mg} / \mathrm{kg}$ and $1000 \mathrm{mg} / \mathrm{kg}$ body weight of aqueous and methanolic extract of Buchholzia coriacea was donerespectively to the parasitized experimental animals.

Thirty-six mice with weight ranging from 20-32g were used for the research study. The mice were grouped into six (A, B, C, D, E and F) of six mice in each group. Group A served as the normal control (no induction, no treatment), group B, served as the experimental control (T.bruceibruceiinduced, but no treatment administered), group C, D, E and F were all induced with the T.brucei brucei dosesintraperitoneally and treated with aqueous and methanolic extracts of the Buchholzia coriacea for 14 days. In groups C, D and E, 3 mice were administered aqueous extract and 3 mice methanolic extract. Berenil at $7 \mathrm{mg} / \mathrm{kg}$ was given to mice in group $\mathrm{F}$ intraperitoneally. By the 4th day of post inoculation, infection had already been established in all the mice in all groups jnoculated. Treatment with graded doses of the extract $(250,500,1000, \mathrm{mg} / \mathrm{kg}$ respectively) started on $\mathrm{d}$ $5^{\text {th }}$ day and was administered intraperitoneally for 5 consecutive days to the mice in (groups C, D, E) and Berenil to group F. Parasitaemia and packed cell volume (PCV) were monitored as already described at 7 days intervals. Body weight and temperature were monitored weekly. Body weight was measured by the use of a sensitive electronic weighing balance.

\section{Collection of blood sample and Haematocrit determination}

The packed cell volume (PCV) was determined with the aid of microhaematocrit centrifuge. A small volume of blood was collected from the tail of the mice into heparinized capillary tubes, filled up to about $2 / 3$ the length, sealed with plasticine and centrifuged at $3000 \mathrm{r} / \mathrm{min}$ for $10 \mathrm{~min}$. The packed cell volume was determined using microhaematocrit reader which gives the value in percentage. 


\section{Results}

The results of the phytochemical analysis show the presence of phytochemical compunds in both aqueous and methanolic extracts as shown in Table 1.

Table1: Phytochemical analysis of dried seed extracts of Buchholzia coriacea.

\begin{tabular}{|l|l|l|}
\hline Phytochemicals & Aqueous extract & Methanolic extract \\
Alkaloids & ++ & + \\
Flavonoids & ++ & + \\
Tannins & ++ & ++ \\
Saponins & + & ++ \\
Steroids & + & + \\
Terpenoids & + & + \\
Anthraquinones & + & + \\
Cardiac glycosides & ++ & ++ \\
\hline
\end{tabular}

Proximate composition of B. coriacea seed shows appreciable percentage of various nutrients with carbohydrate having the highest value of $(77.20 \%)$ and the moisture content having the lowerest percentage (1.34\%) (Table 2).

Table2: Proximate composition of Buchholzia coriacea seeds

\begin{tabular}{|l|l|}
\hline PARAMETER & COMPOSITION (\%) \\
\hline Carbohydrate & 77.20 \\
\hline Crude protein & 13.20 \\
\hline Crude fat & 2.20 \\
\hline Ash content & 4.38 \\
\hline Moisture content & 1.34 \\
\hline Crude fibre & 1.66 \\
\hline
\end{tabular}

The infected and untreated mice in group B shows high levels of parasitaemia (121 and 270) in the day 1 and day 13 respectively which is significantly higher than what is found in the groups infected and treated with different doses of aqueous extract and berenil (Table 3 and figure 1). Whereas, in the groups infected and treated, the parasitaemialevels was higher in day 1 with different doses of extract and berenil $(113,115,100$, and 110 for aqueous extract $250 \mathrm{mg} / \mathrm{kg}, 500 \mathrm{mg} / \mathrm{kg}, 1000 \mathrm{mg} / \mathrm{kg}$ and berenil $7 \mathrm{mg} / \mathrm{kg}$ respectively) (Table 3 and figure 1). There was low level of parasitaemia in day 13 (2) in the group treated with $250 \mathrm{mg} / \mathrm{kg}$ of theaqueous extract whereas no parasitaemia was found in the group treated with berenil, $500 \mathrm{mg} / \mathrm{kg}$ and $1000 \mathrm{mg} / \mathrm{kg}$ of the aqueous extract (Table 3 and figure 1).

Table3: Effect of the varying doses of aqueous extract of Buchholziacoriacea on the level of parasitaemia in mice infected with Trypanosoma brucei brucei.

\begin{tabular}{|l|l|l|l|l|l|l|}
\hline & $\begin{array}{l}\text { GROUP A } \\
\text { Uninfected } \\
\text { Untreated } \\
\text { infection } \\
\text { Days }\end{array}$ & $\begin{array}{l}\text { GROUP B } \\
\text { Infected } \\
\text { Untreated } \\
\text { Infected \& treated } \\
\text { with } \\
250 \mathrm{mg} / \mathrm{kg}\end{array}$ & $\begin{array}{l}\text { GROUP C } \\
\text { Infected \& treated } \\
\text { with } \\
500 \mathrm{mg} / \mathrm{kg}\end{array}$ & $\begin{array}{l}\text { GROUP E } \\
\text { Infected \& treated } \\
\text { with } \\
1000 \mathrm{mg} / \mathrm{kg}\end{array}$ & $\begin{array}{l}\text { GROUP F } \\
\text { Infected \& treated } \\
\text { with } \\
\text { Berenil }\end{array}$ \\
\hline 1 & $0 \pm 0$ & $121 \pm 4$ & $113 \pm 6$ & $115 \pm 5$ & $100 \pm 6$ & $110 \pm 6$ \\
\hline 3 & $0 \pm 0$ & $143 \pm 11$ & $70 \pm 4$ & $43 \pm 2$ & $18 \pm 3$ & $12 \pm 2$ \\
\hline 5 & $0 \pm 0$ & $150 \pm 9$ & $56 \pm 4$ & $19 \pm 2$ & $2 \pm 1$ & $6 \pm 1$ \\
\hline 7 & $0 \pm 0$ & $196 \pm 9$ & $40 \pm 3$ & $7 \pm 1$ & $0 \pm 0$ & $0 \pm 0$ \\
\hline 9 & $0 \pm 0$ & $210 \pm 18$ & $15 \pm 2$ & $3 \pm 1$ & $0 \pm 0$ & $0 \pm 0$ \\
\hline 11 & $0 \pm 0$ & $250 \pm 14$ & $5 \pm 2$ & $0 \pm 0$ & $0 \pm 0$ & $0 \pm 0$ \\
\hline 13 & $0 \pm 0$ & $270 \pm 17$ & $2 \pm 1$ & $0 \pm 0$ & $0 \pm 0$ & $0 \pm 0$ \\
\hline
\end{tabular}

Values are mean \pm SD 


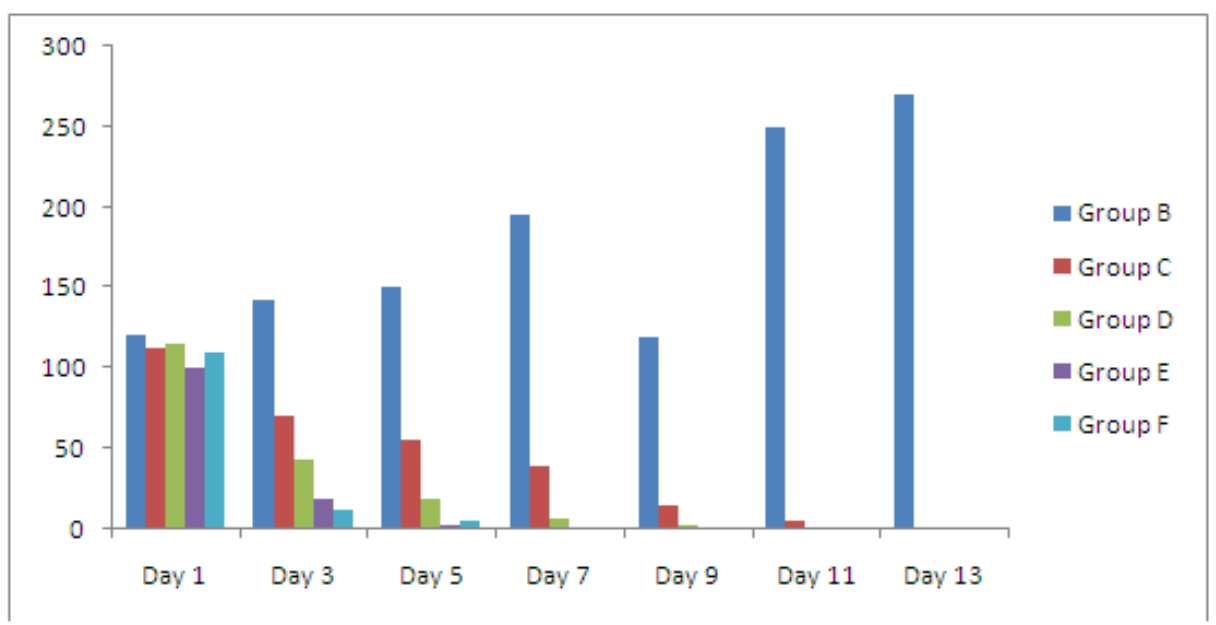

Figure 1: Effect of the varying doses of aqueous extract of Buchholzia coriacea on the level of parasitaemia of mice infected with Trypanosoma brucei brucei.

Similaly, the infected and untreated mice in group B shows high levels of parasitaemia (121 and 270) in the day 1 and day 13 respectively which is significanly higher than what is found in the groups infected and treated with different doses of methanolic extract and berenil (Table 4 and figure 2). Whereas, in the groups infected and treated, the parasitaemia levels were higher in day 1 with different doses of extract and berenil $(119,117,112$, and 110 for methanolic extract $250 \mathrm{mg} / \mathrm{kg}, 500 \mathrm{mg} / \mathrm{kg}, 1000 \mathrm{mg} / \mathrm{kg}$ and berenil $7 \mathrm{mg} / \mathrm{kg}$ respectively) (Table 4 and figure 2). While there was low level of parasitaemia in day $13(25,19$ and 9) for the methanolic extract treated group and no parasitaemia was found in the group treated with berenil.

Table4: Effects of the varying doses of methanolic extract of Buchholzia coriacea on the level of parasitaemia in mice infected with Trypanosoma brucei brucei.

\begin{tabular}{|l|l|l|l|l|l|l|}
\hline $\begin{array}{l}\text { Post infection } \\
\text { Days }\end{array}$ & $\begin{array}{l}\text { GROUP A } \\
\text { Uninfected } \\
\text { Untreated }\end{array}$ & $\begin{array}{l}\text { GROUP B } \\
\text { Infected } \\
\text { Untreated }\end{array}$ & $\begin{array}{l}\text { GROUP C } \\
\text { Infected treated } \\
\text { with } \\
250 \mathrm{mg} / \mathrm{kg}\end{array}$ & $\begin{array}{l}\text { GROUP D } \\
\text { Infected } \\
\text { treated with } \\
500 \mathrm{mg} / \mathrm{kg}\end{array}$ & $\begin{array}{l}\text { GROUP E } \\
\text { Infected } \\
\text { with } \\
1000 \mathrm{mg} / \mathrm{kg}\end{array}$ & $\begin{array}{l}\text { GROUP F } \\
\text { treated } \\
\text { Infected } \\
\text { treated } \\
\text { Berenil } 7 \mathrm{mg} / \mathrm{kg}\end{array}$ \\
\hline 1 & $0 \pm 0$ & $121 \pm 12$ & $119 \pm 11$ & $117 \pm 11$ & $112 \pm 13$ & $110 \pm 7$ \\
\hline 3 & $0 \pm 0$ & $143 \pm 10$ & $110 \pm 11$ & $90 \pm 9$ & $85 \pm 8$ & $12 \pm 2$ \\
\hline 5 & $0 \pm 0$ & $150 \pm 14$ & $85 \pm 9$ & $74 \pm 4$ & $53 \pm 5$ & $6 \pm 1$ \\
\hline 7 & $0 \pm 0$ & $196 \pm 15$ & $72 \pm 10$ & $45 \pm 4$ & $24 \pm 3$ & $0 \pm 0$ \\
\hline 9 & $0 \pm 0$ & $210 \pm 18$ & $50 \pm 8$ & $31 \pm 2$ & $17 \pm 2$ & $0 \pm 0$ \\
\hline 11 & $0 \pm 0$ & $250 \pm 15$ & $25 \pm 6$ & $19 \pm 3$ & $9 \pm 1$ & \\
\hline 13 & $0 \pm 0$ & $270 \pm 13$ & $17 \pm 4$ & $10 \pm 3$ & $3 \pm 1$ & \\
\hline
\end{tabular}

Values are mean \pm SD

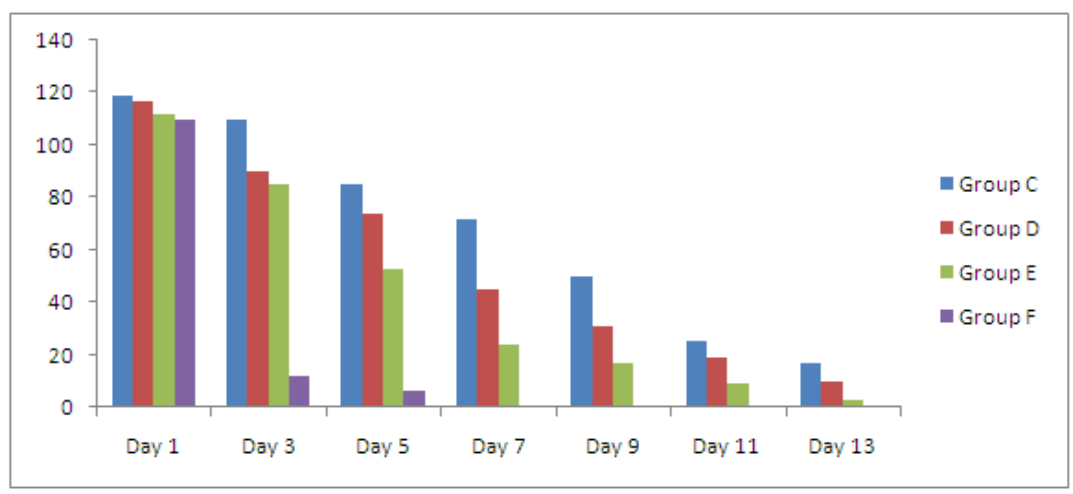

Figure 2: Effects of varying doses of methanolic extract of Buchholzia coriacea on the level of parasitaemia in mice infected with Trypanosoma brucei brucei. 
Proximate Analysis, Phytochemical Screening and Antitrypanocidal Potentials of Bucholzia ....

It was also observed that group A has higher packed cell volume (PCV) than every other group. Group $\mathrm{B}$ which was infected and not treated was observed to have the lowest PCV in the three experimental groups. The group F treated with berenil was observed to have higher PCV than the group treated with different doses of aqueous extract (Table 5 and figure 3).

Table5: Effect of the varying doses of aqueous extract of Buchholzia coriaceaon the level of packed cell volume in mice infected with Trypanosoma brucei brucei

\begin{tabular}{|l|l|l|l|l|l|l|}
\hline $\begin{array}{l}\text { Post infection } \\
\text { Days }\end{array}$ & $\begin{array}{l}\text { GROUP A } \\
\text { Uninfected } \\
\text { Untreated }\end{array}$ & $\begin{array}{l}\text { GROUP B } \\
\text { Infected } \\
\text { Untreated }\end{array}$ & $\begin{array}{l}\text { GROUP C } \\
\text { Infected treated } \\
\text { with } \\
250 \mathrm{mg} / \mathrm{kg}\end{array}$ & $\begin{array}{l}\text { GROUP D } \\
\text { Infected treated } \\
\text { with } \\
500 \mathrm{mg} / \mathrm{kg}\end{array}$ & $\begin{array}{l}\text { GROUP E } \\
\text { Infected } \\
\text { treated with } \\
1000 \mathrm{mg} / \mathrm{kg}\end{array}$ & $\begin{array}{l}\text { GROUP F } \\
\text { Infected } \\
\text { with } \\
\text { Berenil }\end{array}$ \\
\hline 1 & $56 \pm 3$ & $37 \pm 3$ & $39 \pm 2$ & $41 \pm 3$ & $46 \pm 3$ & $48 \pm 1$ \\
\hline 7 & $55 \pm 3$ & $32 \pm 1$ & $43 \pm 4$ & $46 \pm 1$ & $52 \pm 2$ & $55 \pm 4$ \\
\hline 14 & $54 \pm 2$ & $18 \pm 3$ & $47 \pm 4$ & $50 \pm 0$ & $54 \pm 3$ & $58 \pm 2$ \\
\hline
\end{tabular}

Values are mean \pm SD

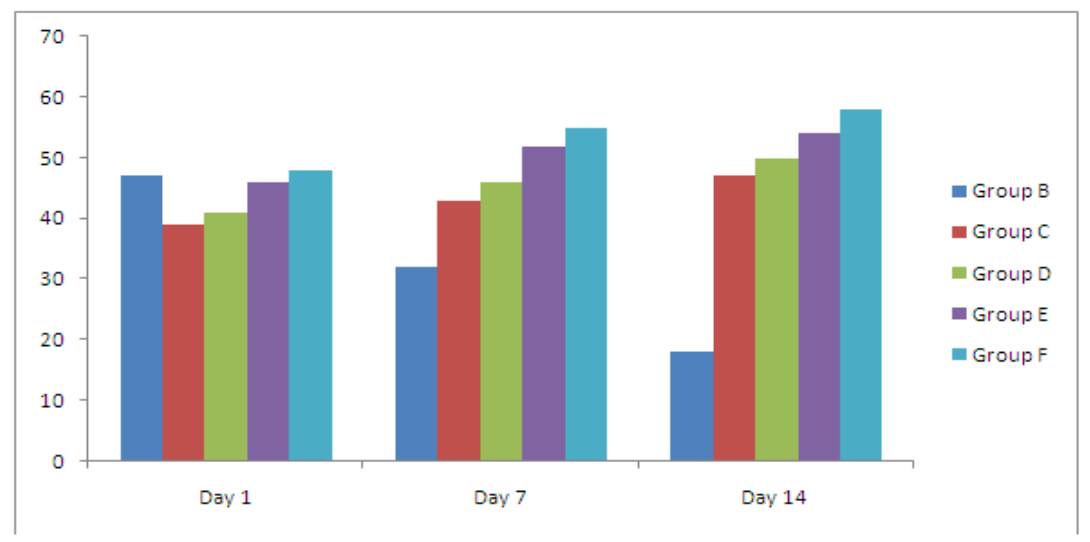

Figure 3: Effect of the varying doses of aqueous extract of Buchholzia coriaceaon the level of PCV in mice infected with Trypanosoma brucei brucei.

It was similalry observed that group A has higher packed cell volume than every other group. Group B which was infected and not treated was observed to have the lowest PCV in the three post infection days. The group F treated with berenil was observed to have higher PCV than the group treated with different doses of methanolic extract as shown in Table 6 and figure 4.

Table6: Effect of the varying doses of methanolic extract of Buchholzia coriacea on the level of PCV in mice infected with Trypanosoma brucei brucei (\%)

\begin{tabular}{|l|l|l|l|l|l|l|}
\hline $\begin{array}{l}\text { Post } \\
\text { infection } \\
\text { Days }\end{array}$ & $\begin{array}{l}\text { GROUP A } \\
\text { Uninfected } \\
\text { Untreated }\end{array}$ & $\begin{array}{l}\text { GROUP B } \\
\text { Infected } \\
\text { Untreated }\end{array}$ & $\begin{array}{l}\text { GROUP C } \\
\text { Infected treated } \\
\text { with } \\
250 \mathrm{mg} / \mathrm{kg}\end{array}$ & $\begin{array}{l}\text { GROUPD } \\
\text { Infected } \\
\text { treatedwith } \\
500 \mathrm{mg} / \mathrm{kg}\end{array}$ & $\begin{array}{l}\text { GROUP E } \\
\text { Infected treated } \\
\text { with } \\
1000 \mathrm{mg} / \mathrm{kg}\end{array}$ & $\begin{array}{l}\text { GROUP F } \\
\text { Infected treated with } \\
\text { Berenil } 7 \mathrm{mg} / \mathrm{kg}\end{array}$ \\
\hline 1 & $56 \pm 2$ & $47 \pm 4$ & $35 \pm 2$ & $36 \pm 1$ & $42 \pm 2$ & $47 \pm 1$ \\
\hline 7 & $55 \pm 4$ & $32 \pm 2$ & $40 \pm 1$ & $42 \pm 4$ & $49 \pm 2$ & $50 \pm 3$ \\
\hline 14 & $54 \pm 1$ & $18 \pm 3$ & $43 \pm 4$ & $49 \pm 3$ & $52 \pm 4$ & $54 \pm 2$ \\
\hline
\end{tabular}




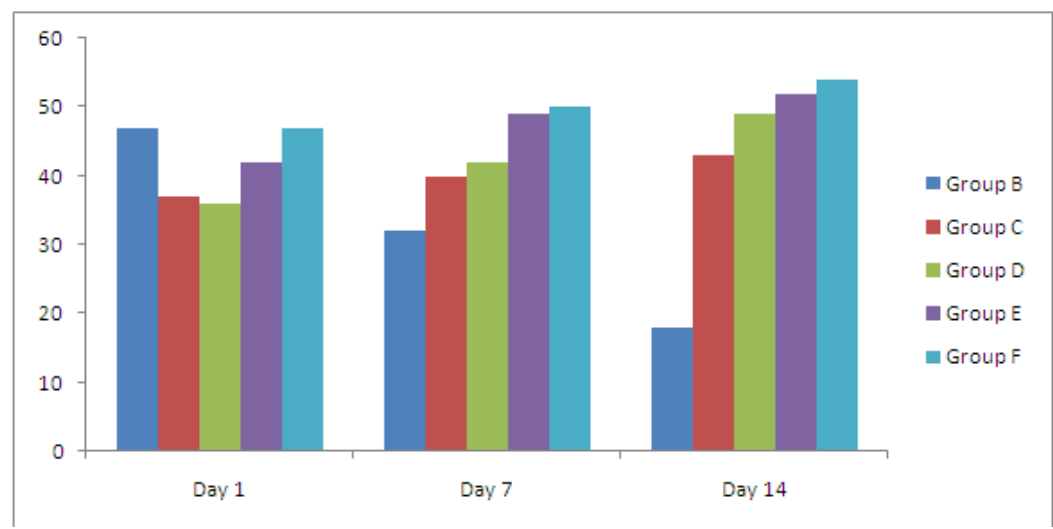

Figure 4: Effect of the varying doses of methanolic extract of Buchholzia coriacea on the level of PCV in mice infected with Trypanosoma brucei brucei.

\section{Proximate analysis}

\section{Discussion}

Many natural food products are reported to have nutritional as well as medicinal capabilities (Atawodi, 2005). Proximate composition of B. coriacea seed shows appreciable percentage of various nutrients with carbohydrate having the highest value of (77.20\%) and the moisture content having the lowest percentage (1.34\%). This shows that B. coriacea seed can serve as a good source of nutrient.

\section{Phytochemical analysis}

The curative properties of plant derived drugs are due to the presence of complex chemical substances of varied composition in one or more parts of the plants. Polyphenols are abundant in our diet, and play important role in the prevention of various diseases associated with oxidative stress (Claudine et al., 2004). Phytochemical analysis of the seeds of B. coriacea shows presence of phytochemical compounds indicating that the seeds have medicinal properties. Epidemiological studies have suggested associations between the consumption of polyphenol-rich foods or beverages and the prevention of diseases (Atawodi et al., 2009). Fruit and vegetable consumption prevents cancers. It may also prevent stroke, whereas wine consumption might prevent coronary heart disease. The consumption of tea may protect against cancers and coronary heart diseases, and that of soy may protect against breast cancer and osteoporosis (Claudine et al., 2004).

\section{Effect on the level of parasitaemia}

Parasitaemia was observed to steadily decrease as treatment progressed as shown in table 5 and 6 for both extracts. The effect was dose dependent as $1000 \mathrm{mg} / \mathrm{kg}$ cleared the parasites alongside the standard drug (Berenil $7 \mathrm{mg} / \mathrm{kg}$ ). The $250 \mathrm{mg} / \mathrm{kg}$ and $500 \mathrm{mg} / \mathrm{kg}$ treated groups, showed some level of decrease but not as efficient as the $1000 \mathrm{mg} / \mathrm{kg}$ treated group. There was a decrease from the $3^{\text {rd }}$ to $13^{\text {th }}$ day post inoculations. In the $1000 \mathrm{mg} / \mathrm{kg}$ and Berenil treated groups, parasitaemia decreased from the onset of $5^{\text {th }}$ to $13^{\text {th }}$ days post inoculation for methanolic extract respectively. Nweze, et al.,(2009). The level of parasitaemia in the $250 \mathrm{mg} / \mathrm{kg}$ treated group decreased from the $3^{\text {rd }}$ day post inoculation, up till the end of the experiment but not as in the other treated groups. In $500 \mathrm{mg} / \mathrm{kg}$ extract there was clearance of parasitaemia from the $11^{\text {th }}$ to $13^{\text {th }}$ day post inoculation to the end of the experiment which indicate the ability of the extracts in clearing parasite in an infected animal or subject.

\section{Effect on the level of packed cell volume}

In the negative control group(infected untreated group), parasitaemia rose till the end of the experiment characterized by a fall in the level of PCV value which dropped below the normal. This was as a result of the trypanosome spreading from the primary site of infection to lymph nodes and blood tissues where they continue to replicate (Nyako, et al., (1990). Immunologic lesions are significant in trypanosomiasis resulting in the deposition of immune complexes that prevents normal organ function (Investigated by Cross, 2005). The level of PCV in $250 \mathrm{mg} / \mathrm{kg}$ and $500 \mathrm{mg} / \mathrm{kg}$ extract treated groups decreased from infection day till the $8^{\text {th }}$ day. The 
level of PCV in Berenil (standard control) treated group decreased from onset of infection till the $5^{\text {th }}$ day after which it continued to increase till the end of the experiment. The level of PCV in the Berenil treated group was higher than the $1000 \mathrm{mg} / \mathrm{kg}$ extract treated group. The level of PCV of the uninfected untreated group was significantly higher than that of the infected untreated group whose level of PCV continued to decrease till the end of the work.

One known clinical sign of trypanosomiasis is anaemia as described by Nweze et al., (2009). In this experiment, infected animals had reductions in their PCV following infection. So also was an increase when treatment was administered. The increase was dose dependent and may have resulted from the effect of treatment as there was a steady reduction in parasitaemia as shown by the aqueous and methanolic extracts. This finding suggests that the aqueous extract of Buchholzia coriacea seed has antitrypanocidal activity in mice experimentally infected with Trypanosoma brucei brucei than the methanolic extract of Buchholzia coriacea.

\section{Conclusion}

Extracts of B. coriacea shows appreciable amount of nutrients and presence of phytochemical compounds as well as anti-trypanocidal activity in mice induced with Trypanosoma brucei brucei of whichaqueous extractshowedbetteranti-trypanocidal activity than the methanolic extract. These extracts are cheaper and readily available than the current expensive drugs commercially in use. Farmers are hereby encouraged to make use of these active therapeutic agents to reduce management costs.

\section{References}

[1]. Association of Official Analytical Chemists (AOAC, 1990). Official methods of analysis of the Association of Analytical Chemists, 16th Edition. Washington D.C

[2]. Arolowo, R.O.A (1997). Medicinal plants. Chairman's address at the herbal day programme titled "the application of herbal medicines in livestock production" organized by animal care services consult (nig.) ltd. Agege, Lagos. Held at the $34^{\text {th }}$ NVMA congress, Osogbo, osun state.

[3]. Atawodi, S. E. (2005): Antioxidant potential of African medicinal plants. African Journal ofBiotechnolog,. 4 (2): 128-133.

[4]. Atawodi, S.E., Atawodi, J.C., Pala Y Idakwo P. (2009) Assessment of the Polyphenol Profile and Antioxidant Properties of Leaves, Stem and Root Barks of Khaya senegalensis (Desv.). Electronic Journal of Biology,5(4):80 - 84

[5]. Aderbauer B, Clausen P-H, Kershaw O, Melzig M F.(2008).In vitro and in vivo trypanocidal effect of lipophilic extracts of medicinal plants from Mali and Burkina Faso. J Ethnopharmacol.119:225-231.

[6]. Asuzu I. U, Anaga A. O. (1991).Pharmacological screening of the aqueous extract of Alstoniabooneibark.Fitoterapia LXII.5:411417.

[7]. Asuzu I U, Chineme C N. (1990). Effects of Morindalucida leaf extract on Trypanosomabruceibrucei infection in mice. J Ethnopharmacol.30:307- 313.

[8]. Claudine, M.Augustin, S. Christine, M. Christian, R. and Liliana, J. (2004). Polyphenols: food sources and bioavailability. Am J ClinNutr,79:727-47.

[9]. Cross, G.A.M (2005). Antigenic variation in trypanosomes.Proc.Roy.Socland 200:55-72

[10]. Edeoga, H. O., Okwu, D. E., and Mbaebie, B. O. (2005).Phytochemical constituents of some Nigerian medicinalplants.Afr J Biotechnol, 4:685-688.

[11]. Focho, D. A. Ndam, W. T. and Fonge, B. A. (2009). Medicinal plants of Aguambu -Bamumbu in the Lebialem highlands, southwest province of Cameroon. African Journal of Pharmacy and Pharmacology. 3(1): 001-013.

[12]. Freiburghaus F, Kaminsky R, Nkunya M H H, Brun R. (1996). Evaluation of African medicinal plants for their in vitrotrypanocidalactivity.J Ethnopharmacol.55:1-11.

[13]. Herbert W J, Lumsden W H R. (1976).Trypanosomabrucei: a rapid 'matching' method for estimating the host's parasitaemia. ExpParasitol. 40:427-431.

[14]. Nweze N E, Fakae L B, Asuzu I U. (2009).Trypanocidal activity of the ethanolic extract of Buchholziacoriaceaseed.Nig Vet J.;29(4):1-6.

[15]. Nyako, J.H.P, Ole-moiyoi, O.K. Majiwa, P.A.O, Otieno, L.H and Ociba, P.M. (1990). Characterization of trypanosomes isolates from cattle in Uganda using species-specific DNA probes reveal predominance of mixed infections insect. Sciapplic 271-281

[16]. Omamegbe J O, Orajaka L J E, Emehelu C O. (1984). The incidence and clinical forms of naturally occurring canine trypanosomiasis in two veterinary clinics in Anambra State of Nigeria.Bull An Health Prod. 32:23-29.

[17]. Parekh, Jand and Chanda, S. V (2007). In vitro antimicrobial activity and phytochemical analysis of some Indian medicinal plants. Turk J Biol, 31:53-58.

[18]. Wurochekke A U, Nok A J. (2004).In vitroantitrypanosomal activity of some medicinal plants used in the treatment of Trypanosomosis in Northern Nigeria.Afr J Biotechnol.3:481-483. 